\title{
Spatio-temporal differentiation in the population structure of Hydrobia ulvae on an intertidal mudflat (Marennes-Oléron Bay, France)
}

\author{
A.-G. Haubois ${ }^{\dagger \neq}$, J.-M. Guarini ${ }^{\dagger}$, P. Richard ${ }^{\dagger}$, G.F. Blanchard* ${ }^{*}$ and P.-G. Sauriau ${ }^{\dagger}$ \\ *Université de La Rochelle, Laboratoire de Biologie et Environnement Marins (EA3168), Institut du Littoral, bâtiment Marie Curie, \\ Rue Enrico Fermi, 17000 La Rochelle, France. ${ }^{\dagger}$ Centre de Recherche en Ecologie Marine et Aquaculture de L'Houmeau \\ CNRS-IFREMER (UMR10), BP 5, 17137 L'Houmeau, France. ${ }^{\ddagger}$ Corresponding author, e-mail: aghauboi@ifremer.fr
}

\begin{abstract}
Spatio-temporal changes in density, breeding cycle, growth and population structure of Hydrobia ulvae (Gastropoda: Prosobranchia) were studied by monthly sampling of a wide bare mudflat in MarennesOléron Bay. Four stations, located along a cross-shore transect and characterized by different geomorphological structures, were investigated from March 2000 to February 2001. Hydrobia ulvae was mainly distributed in the upper half part of the mudflat and no individuals were found in the lower part. The breeding cycle extended from March to December and showed two annual peaks, in spring and in autumn. Three cohorts were recruited during the year and showed high growth rates during summer; the parameters of the von Bertalanffy model describing the growth curves were equal to $\mathrm{k}_{\max }=0.47 \pm 0.5 \mathrm{~mm}$ month $^{-1}$ and $\mathrm{L}_{\infty}=5.4 \pm 0.2 \mathrm{~mm}$. The snail population had similar size-frequency structure along the transect at the beginning of the survey but summer recruitment initiated spatial differentiation. Reproduction occurred in the middle part of the mudflat but recruits mainly settled down at the upper level of the mudflat; new cohorts appeared with increasing individual densities. The middle part of the mudflat was rather dominated by adult individuals which showed large density fluctuations.
\end{abstract}

\section{INTRODUCTION}

Hydrobia ulvae (Pennant) is one of the most common deposit-feeders in European intertidal mudflats (Newell, 1979). This snail feeds on different sources of organic matter at the mud surfaces (Newell, 1965; Jensen \& Siegismund, 1980) and microphytobenthos, which is the main source of primary production in intertidal mudflats (Admiraal, 1984; Colijn \& de Jonge, 1984; Blanchard \& Guarini, 1998), have been reported to be its major source of nutrition (Fenchel et al., 1975; Lopez \& Kofoed, 1980; Morrissey, 1988). In addition, $H$. ulvae may provide an important food source for secondary consumers like birds (Evans, 1987) and fish (Aarnio \& Mattila, 2000). It is thus considered as an important link in the intertidal food web. In Marennes-Oléron Bay, where mudflats extend over $\sim 60 \%$ of the whole bay area, H. ulvae can reach several thousands of individuals $\mathrm{m}^{-2}$ (Sauriau et al., 1989) and is supposed to have a strong impact on microphytobenthic biomass (Cariou-Le Gall \& Blanchard, 1995). Nevertheless, the functional role of the species cannot be quantified because its population dynamics had not been studied.

Studies of the population dynamics of $H$. ulvae in different areas (Fish \& Fish, 1974; Bachelet \& YassineKassab, 1987; Barnes, 1990; Lillebo et al., 1999) revealed a latitudinal trend in the breeding cycle and growth. Several authors have also recorded temporal variations of the density which were not the result of recruitment or mortality processes (Sola, 1996; Barnes, 1998; Barnes \& de Villiers, 2000) and Fish \& Fish (1974) recorded a differential distribution between juveniles and adults. Hydrobia ulvae has a pelagic larval stage (Fish \& Fish,
1974) and a floating capacity (Little \& Nix, 1976). Armonies (1992) and Armonies \& Hartke (1995) showed a high dispersion of juveniles of $H$. ulvae by a drifting behaviour, a phenomenon already reported for other benthic species (Armonies, 1994; Olivier et al., 1996; Blackmon \& Eggleston, 2001). In addition, individuals may also be passively rolled by flooding tides which may induce temporal variation in natural abundances, more particularly during spring tides (Barnes, 1998). Consequently, densities are susceptible to show a spatiotemporal dynamics; this suggested that sampling at a single station is not adequate to understand processes involved in population density changes.

The objective of this study was to investigate the population dynamics of $H$. ulvae at different locations on a mudflat, to determine processes which can be estimated at a local scale and processes involving a larger scale. For this, the spatio-temporal evolution of the population structure of $H$. ulvae was investigated along a cross-shore transect during one year. Classical tools of population dynamics were used to estimate unknown parameters from observed samples. The breeding cycle was characterized by the percentages of individuals bearing egg capsules and population structure and growth were investigated by statistical analyses.

\section{MATERIALS AND METHODS}

Study area

Brouage mudflat is located on the eastern side of the Marennes-Oléron Bay along the French Atlantic coast 


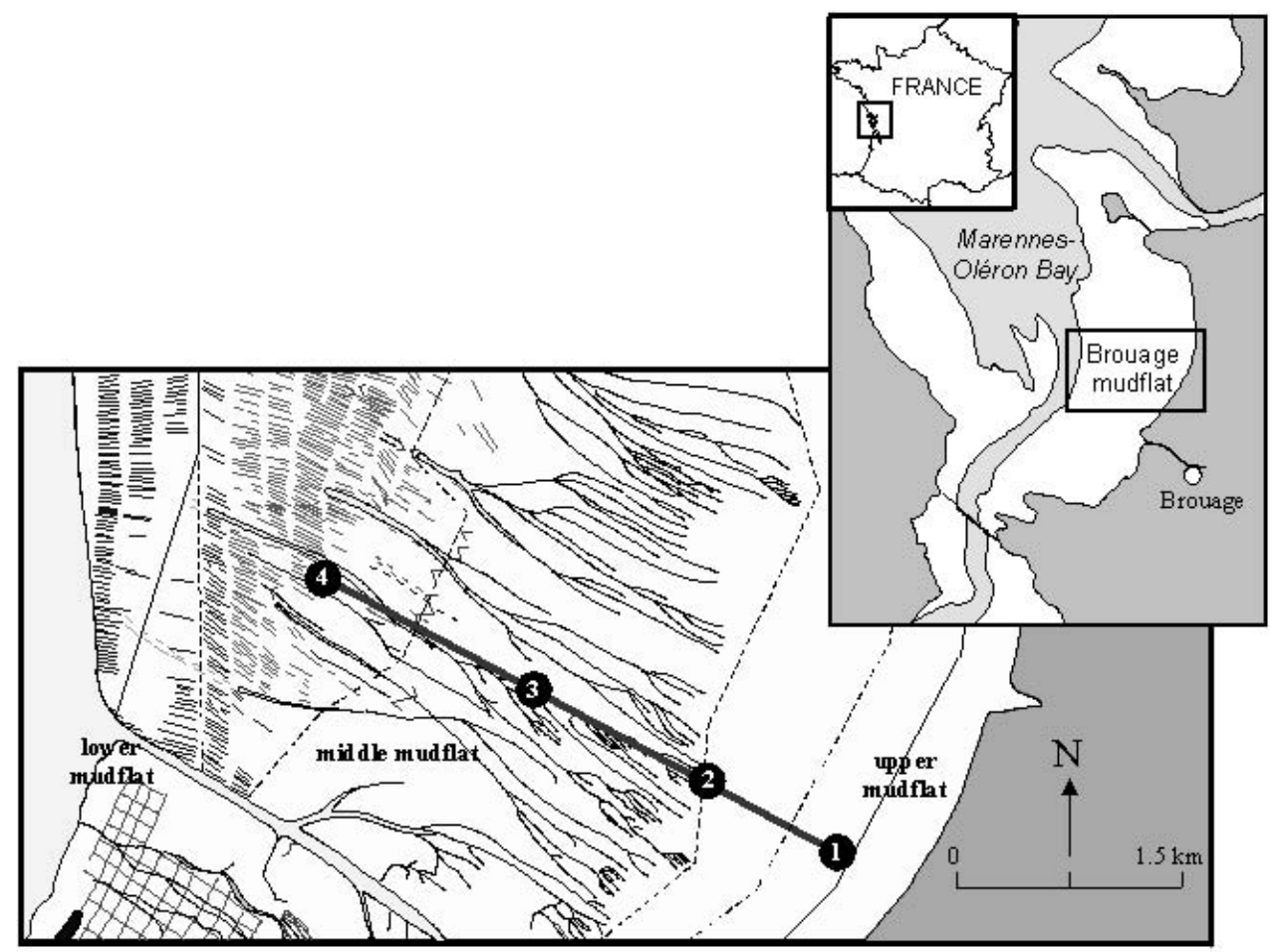

Figure 1. Position of sampling stations along a cross-shore transect on Brouage mudflat.

$\left(46^{\circ} 25^{\prime} \mathrm{N} 01^{\circ} 10^{\prime} \mathrm{W}\right)$. This intertidal area is more than $4 \mathrm{~km}$ wide and the sediment consists of silt and clay particles $(95 \%<63 \mu \mathrm{m})$. Three zones can be distinguished (Figure 1): (i) the upper mudflat (500 $\mathrm{m}$ wide) is flat, strongly affected by meteorological conditions and characterized by rapid changes of erosion/sedimentation events (Gouleau et al., 2000); (ii) the middle mudflat $(3000 \mathrm{~m}$ wide) is typical of a ridge and runnel structure area; and (iii) the lower mudflat ( $\sim 800 \mathrm{~m}$ wide) is used for mussel culture.

\section{Sampling}

The population dynamics of Hydrobia ulvae was investigated from March 2000 to February 2001 along a cross-shore transect which encompasses the main geomorphological units. At Station 1, in the upper mudflat, erosion structures appeared in spring and winter and observed crests and troughs were distinctively sampled. Stations 2 and 3 were located in the middle mudflat; ridges and runnels were both sampled. A fourth lower intertidal site was also sampled but never contained Hydrobia and is therefore not further mentioned. Six random replicates of $15 \mathrm{~cm}$ in diameter within $1 \mathrm{~m}^{2}$ of mud were taken and the top $5 \mathrm{~cm}$ layer of sediment was sieved through a $500-\mu \mathrm{m}$ mesh. The number of snails were counted and their shell length, from apex to anterior margin of the aperture, was measured. The breeding cycle was characterized in terms of percentage of individuals carrying egg masses.

\section{Data analysis}

Size-frequency distributions were established for each date, station and sedimentary structure using a $0.1 \mathrm{~mm}$ size-class. A statistical analysis was performed on size-frequency histograms to separate different cohorts (groups of individuals recruited during a fixed period of time) from the mixed population of $H$. ulvae. This analysis relies on the assumption that the size distribution of a cohort follows a gaussian pattern. From the same observed size distribution $\mathrm{K}$ normal components were thus identified. Each component has been described by three parameters: $\mu$ (the mean), $\sigma$ (the standard deviation) and $\mathrm{p}$ (the amplitude). The number of components $\mathrm{K}$ was fixed a priori, based on the biological cycle of the species (extension of the spawning period, time lag between spawning peaks and recruitments, life span of snails) and the definition of class resolution. Estimates of the $\mathrm{K}$ parameter sets $\hat{\theta}_{\mathrm{k}}=\left\{\hat{\mu}_{\mathrm{k}}, \hat{\sigma}_{\mathrm{k}}, \hat{\mathrm{p}}_{\mathrm{k}}\right\}$ were performed without constraint by minimizing the maximum log-likelihood criteria, $\mathrm{L}_{t}$ (Hasselblad, 1966). At step t:

$$
\left\{\begin{array}{l}
\hat{\mathrm{q}}_{\mathrm{t}, \mathrm{nk}}=\exp \left\{-\left(\mathrm{x}_{\mathrm{i}}-\hat{\mu}_{\mathrm{t}, \mathrm{k}}\right)^{2} /\left(2 \hat{\sigma}_{\mathrm{t}, \mathrm{k}}^{2}\right)\right\} /\left(\hat{\sigma}_{\mathrm{n}, \mathrm{k}} \sqrt{2 \pi}\right) \\
\hat{\mathrm{Q}}_{\mathrm{t}, \mathrm{n}}=\sum_{\mathrm{k}=1}^{\mathrm{K}} \hat{\mathrm{p}}_{\mathrm{t}, \mathrm{k}} \cdot \hat{\mathrm{q}}_{\mathrm{t}, \mathrm{nk}} \\
\hat{\mathrm{L}}_{\mathrm{t}}=\sum_{\mathrm{n}=1}^{\mathrm{N}} \mathrm{f}_{\mathrm{n}} \cdot \ln \left(\hat{\mathrm{Q}}_{\mathrm{t}, \mathrm{n}}\right)
\end{array}\right.
$$

where $x_{i}$ is the centre of the size class $i$.

The steepest descent algorithm was used (Tomlinson, 1970) after determining initial values, calculating observed frequencies $f_{n}$ and rescaling size-classes (each size-class was equal to 1). Only the populations with $\mathrm{N}>500$ were analysed. Total abundances of each group were calculated from estimated cohorts by numerical integration which allowed checking of the density conservation through the modal analysis. 
Growth

In order to describe the growth rate of $H$. ulvae, a dynamic model was fitted to the observed growth curves, obtained by tracking the estimated mean size of identified cohorts. The model is the von Bertalanffy equation:

$\frac{\mathrm{d} \mathrm{L}}{\mathrm{dt}}=\mathrm{k}(\mathrm{t})\left(\mathrm{L}_{\infty}-\mathrm{L}\right)$

where $\mathrm{L}_{\infty}$ is an asymptotic fitted value representing the maximum mean individual size and $\mathrm{k}(\mathrm{t})$ is a sinusoidal function representing the seasonal variation of the growth rate (Cloern \& Nichols, 1972):

$\mathrm{k}(\mathrm{t})=\mathrm{k}_{\max }(0.5+0.5 \sin (\omega \mathrm{t}+\varphi))$

The parameter $\omega$ is fixed to correspond to a one-year periodicity. The 3 -parameter vector $\theta\left\{\mathrm{k}_{\max }, \mathrm{L}_{\infty}, \varphi\right\}$ was estimated using a Simplex Algorithm (Nelder \& Mead, 1965) which minimizes an Ordinary Least Square criterion $\left(\mathrm{Y}_{\mathrm{OLS}}\right)$ :

$\mathrm{Y}_{\mathrm{OLS}}=\min \sum_{\mathrm{i}=1}^{\mathrm{N}}\left(\mathrm{L}_{\mathrm{obs}, \mathrm{i}}-\mathrm{L}_{\mathrm{sim}, \mathrm{i}}\right)^{2}$

where $\mathrm{L}_{\mathrm{obs}, \mathrm{i}}$ corresponds to the estimated mean size of each cohort at time $\mathrm{i}$ (sampling dates); and $\mathrm{L}_{\text {sim, } \mathrm{i}}$ are the corresponding simulated values at time i. Numerical simulations were performed using a 4th-order Runge-Kutta
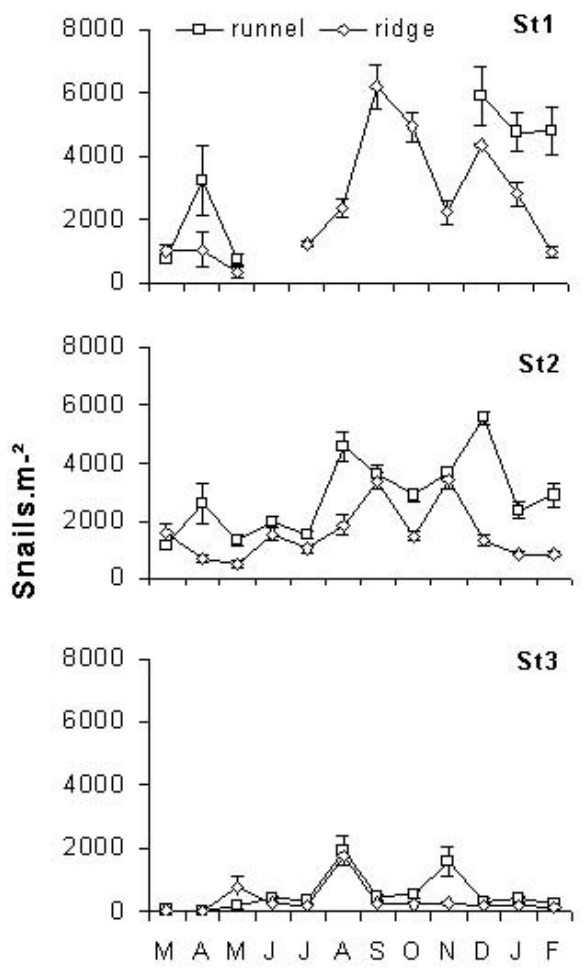

Figure 2. Abundance $\pm \mathrm{SE}$ of Hydrobia ulvae along a cross-shore transect at three stations (Stations 1-3) and in both ridge and runnel structures between March 2000 and February 2001.

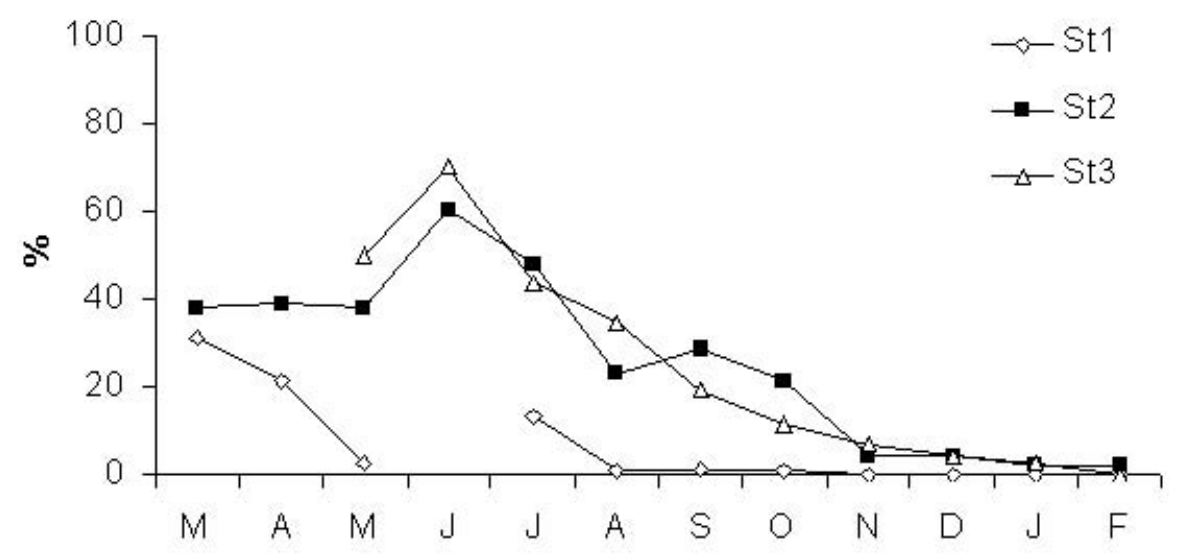

Figure 3. Percentage of Hydrobia ulvae bearing eggs capsules at Stations 1-3 along a cross-shore transect between March 2000 and February 2001.

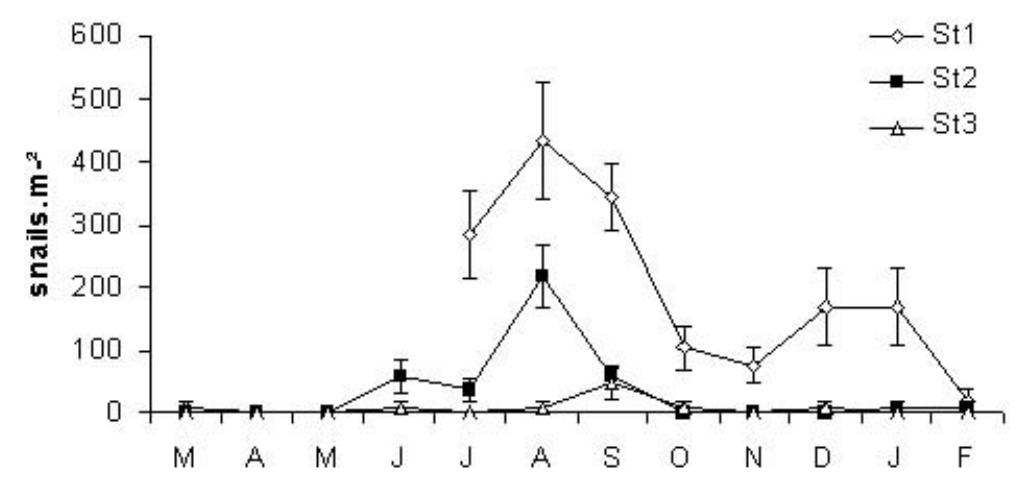

Figure 4. Density of snails (individuals $\mathrm{m}^{-2}$ ) $\pm \mathrm{SE}$ smaller than $1 \mathrm{~mm}$ at Stations 1,2 and 3. 

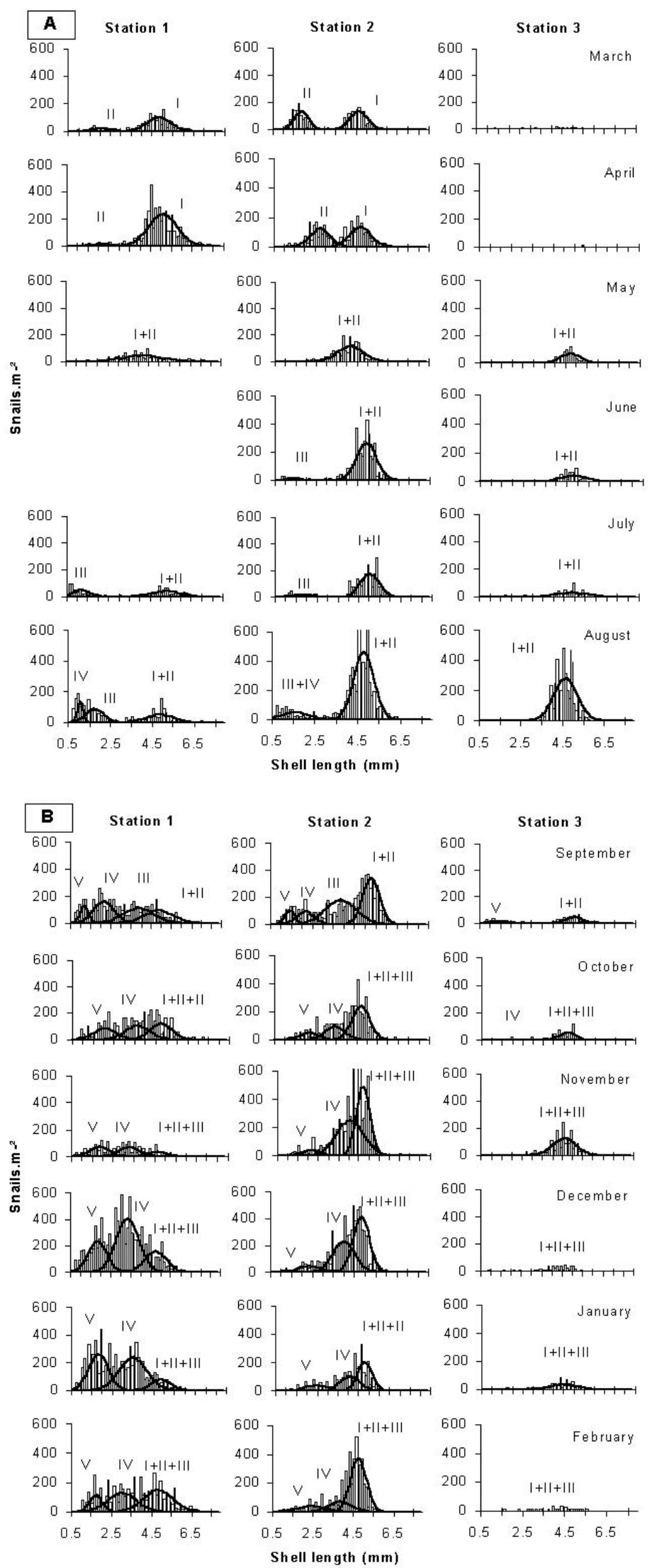

Figure 5. (A) Size-frequency distribution of Hydrobia ulvae along a cross-shore transect between March 2000 and August 2000 at Stations 1, 2 and 3. Identified cohorts are labelled I through V; I+ II means that cohorts I and II have merged in a single cohort; I + II + III means that cohort III has merged with the mixed cohort I+ II; (B) size-frequency distribution of Hydrobia ulvae along a cross-shore transect between September 2000 and February 2001 at Stations 1, 2 and 3. Identified cohorts are labelled I through V; I + II means that cohorts I and II have merged in a single cohort; I + II + III means that cohort III has merged with the mixed cohort I+ II. 
Table 1. Estimated parameters from cohort analysis.

\begin{tabular}{|c|c|c|c|c|c|c|c|c|c|c|c|c|c|}
\hline & & M & A & M & $\mathrm{J}$ & $\mathrm{J}$ & A & $\mathrm{S}$ & $\mathrm{O}$ & $\mathrm{N}$ & $\mathrm{D}$ & $\mathrm{J}$ & $\mathrm{F}$ \\
\hline \multicolumn{14}{|c|}{ Station 1} \\
\hline \multirow[t]{2}{*}{ I } & $\mu$ & 4.1 & 5.1 & & & & & & & & & & \\
\hline & $\mathrm{s}$ & 0.6 & 0.7 & & & & & & & & & & \\
\hline \multirow[t]{2}{*}{ II } & $\mu$ & 2.0 & 2.2 & 4.2 & & 5.2 & 4.8 & 4.8 & & & & & \\
\hline & $\mathrm{s}$ & 0.5 & 0.5 & 0.9 & & 0.7 & 0.6 & 0.8 & & & & & \\
\hline \multirow[t]{2}{*}{ III } & $\mu$ & & & & & 1.1 & 1.7 & 3.6 & 4.7 & 4.5 & 4.7 & 4.8 & 4.8 \\
\hline & $\mathrm{s}$ & & & & & 0.4 & 0.4 & 0.8 & 0.5 & 0.5 & 0.5 & 0.5 & 0.7 \\
\hline \multirow[t]{2}{*}{ IV } & $\mu$ & & & & & & 1.0 & 2.1 & 3.6 & 3.2 & 3.3 & 3.5 & 3.0 \\
\hline & $\mathrm{s}$ & & & & & & 0.1 & 0.5 & 0.6 & 0.5 & 0.6 & 0.7 & 0.7 \\
\hline \multirow[t]{2}{*}{$\mathrm{V}$} & $\mu$ & & & & & & & 1.1 & 2.0 & 1.8 & 1.8 & 1.8 & 1.7 \\
\hline & $\mathrm{s}$ & & & & & & & 0.2 & 0.5 & 0.5 & 0.5 & 0.5 & 0.3 \\
\hline \multicolumn{14}{|c|}{ Station 2} \\
\hline \multirow[t]{2}{*}{ I } & $\mu$ & 4.6 & 4.7 & & & & & & & & & & \\
\hline & s & 0.4 & 0.5 & & & & & & & & & & \\
\hline \multirow[t]{2}{*}{ II } & $\mu$ & 1.9 & 2.7 & 4.1 & 4.9 & 5.0 & 4.8 & 5.3 & & & & & \\
\hline & $\mathrm{s}$ & 0.3 & 0.5 & 0.6 & 0.5 & 0.5 & 0.5 & 0.4 & & & & & \\
\hline \multirow[t]{2}{*}{ III } & $\mu$ & & & & 1.3 & 1.8 & & 3.8 & 4.7 & 4.7 & 4.8 & 4.8 & 4.7 \\
\hline & $\mathrm{s}$ & & & & 0.4 & 0.6 & & 0.7 & 0.4 & 0.3 & 0.4 & 0.4 & 0.4 \\
\hline \multirow[t]{2}{*}{ IV } & $\mu$ & & & & & & 1.5 & 2.1 & 3.4 & 4.0 & 4.1 & 4.1 & 3.8 \\
\hline & $\mathrm{s}$ & & & & & & 0.6 & 0.4 & 0.5 & 0.7 & 0.5 & 0.5 & 0.6 \\
\hline \multirow[t]{2}{*}{ V } & $\mu$ & & & & & & & 1.4 & 2.1 & 2.1 & 2.4 & 2.4 & 2.4 \\
\hline & s & & & & & & & 0.2 & 0.4 & 0.5 & 0.5 & 0.6 & 0.7 \\
\hline \multicolumn{14}{|c|}{ Station 3} \\
\hline \multirow[t]{2}{*}{ I } & $\mu$ & & & 4.7 & 4.8 & 4.8 & 4.6 & 5.0 & 4.6 & 4.6 & 4.3 & 4.5 & \\
\hline & $\mathrm{s}$ & & & 0.5 & 0.6 & 0.6 & 0.7 & 0.4 & 0.5 & 0.6 & 0.9 & 0.6 & \\
\hline
\end{tabular}

$\mu$, means; s, standard deviations.

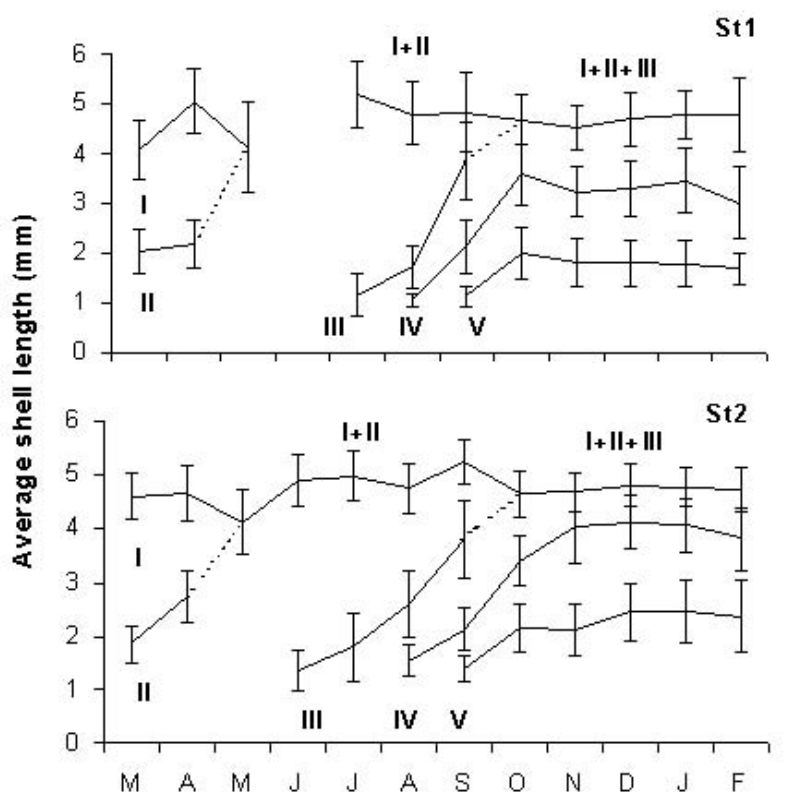

Figure 6. Average shell length ( $\mathrm{mm}$ ) of Hydrobia ulvae cohorts on Brouage mudflat between March 2000 and February 2001 at Stations 1 and 2. Cohorts are labelled I through V; I+ II means that cohorts I and II have merged in a single cohort; I+ II + III means that cohort III has merged with the mixed cohort I+II.
Algorithm. We have added the estimation of initial conditions to the process of global optimization of the vector $\theta$.

\section{RESULTS}

Spatio-temporal distribution of Hydrobia ulvae

During the overall sampling period, Hydrobia ulvae mainly occurred in the upper part of the mudflat (Stations $1 \& 2$ ), with lower densities in the middle part at Station 3 (Figure 2; Kruskal-Wallis test adjusted for ties, $P<0.001$ for both ridges and runnels). Maximum abundances were observed at Stations 1 and 2 with mean annual densities of $4334 \pm 892$ ind $\mathrm{m}^{-2}$ and $4380 \pm 556$ ind $\mathrm{m}^{-2}$, respectively. At Station 3, the mean annual density only reached

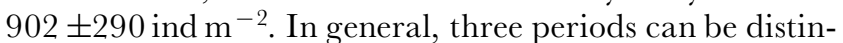
guished: (1) from March-July, densities of $H$. ulvae remained low with about 2000 ind $\mathrm{m}^{-2}$ at Stations 1 and 2 and about 100 ind $\mathrm{m}^{-2}$ at Station 3; (2) from AugustDecember, H. ulvae showed higher densities, especially at Stations 1 (maximum of 6215 ind $\mathrm{m}^{-2}$ in September) and 2; (3) from December to February densities decreased. Hydrobia ulvae abundances were significantly higher in runnels than on ridges at Station 1 when bedforms could be distinguished (1-sample $t$-test, $P=0.020)$ and at Station 2 (1-sample $t$-test, $P=0.003$ ). 


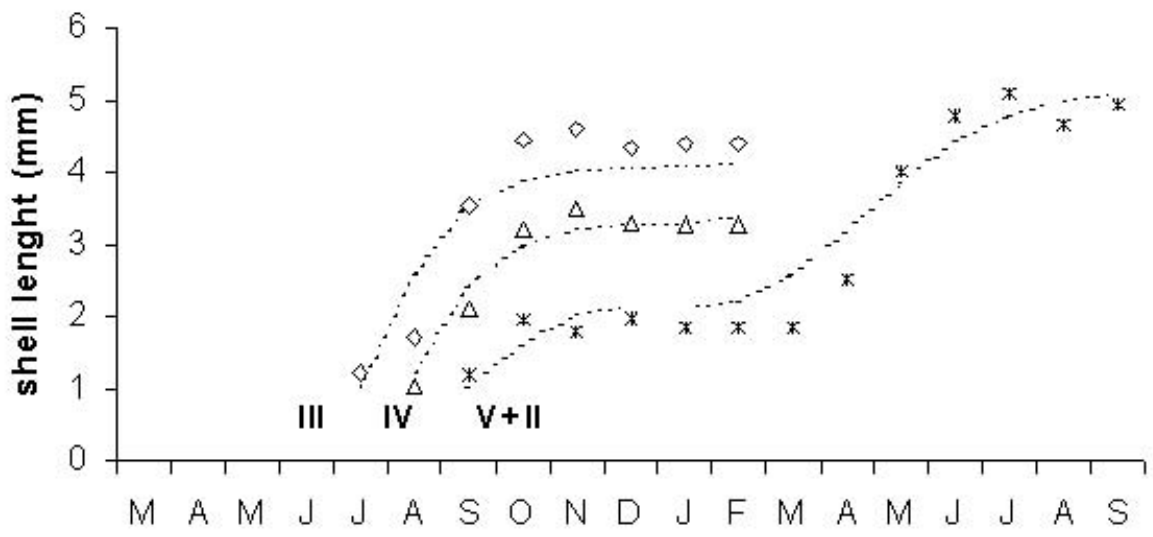

Figure 7. Reconstructed annual growth curves $(\boldsymbol{*}$ ) from observed data (symbols, data from the different Stations 1,2 and 3 were pooled together): assuming a steady state, values of cohort II (corresponding to March-September 2000) were moved at the end of data from cohort V (September 2000-February 2001). A dynamic model, based on von Bertalanffy equation including a variable growth parameter, was then fitted to the observed data to estimate the asymptotic maximum length $\left(\mathrm{L}_{\infty}\right)$ and the maximum growth rate $\left(\mathrm{k}_{\max }\right)$ over the annual cycle.

\section{Breeding cycle and recruitment}

The breeding period of $H$. ulvae on Brouage mudflat extended from March-November and the individuals carrying egg capsules were mostly found in the middle part of the mudflat (Stations $2 \& 3$, see Figure 3). At these stations, the spawning peak occurred between May and July with a maximum value in June (with $\sim 60 \%$ of snails carrying egg capsules); a secondary
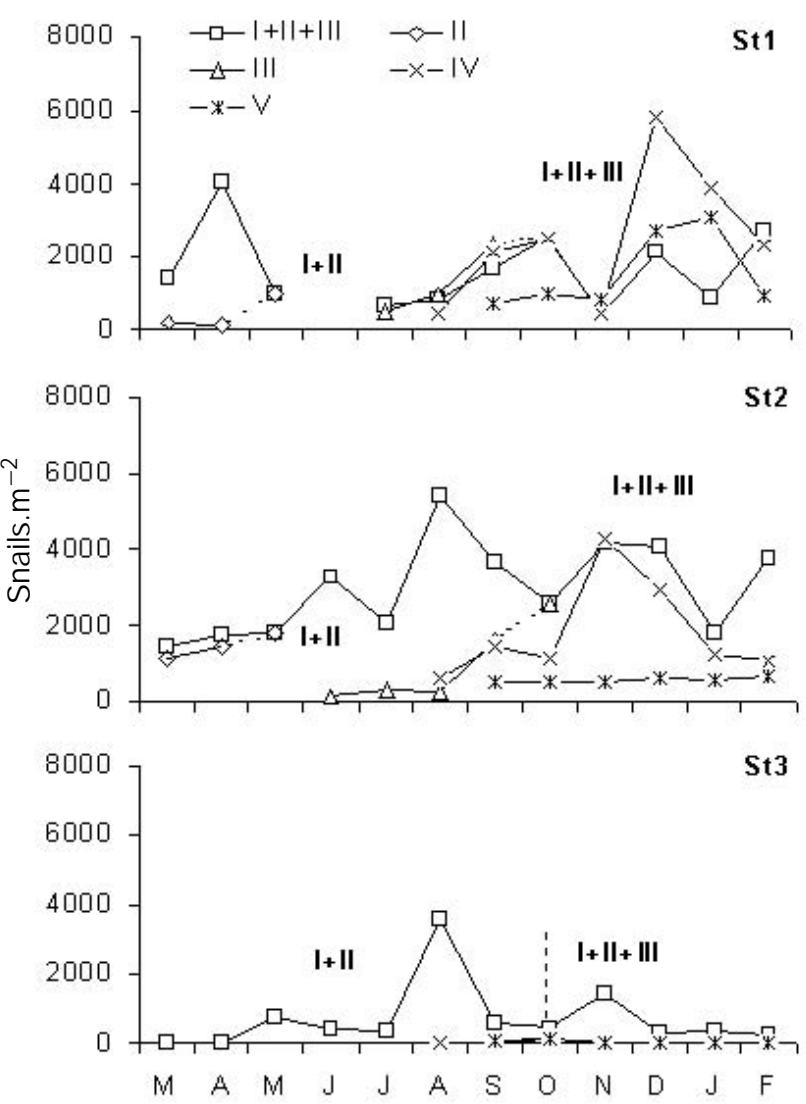

Figure 8. Abundance of each cohort at Stations 1, 2 and 3 between March 2000 and February 2001. Cohorts are labelled I through V; I + II means that cohorts I and II merged in a single cohort; I+ II + III means that cohort III has merged with the mixed cohort I+II. peak occurred at Station 2 between September and October. At Station 1, the observed pattern was different with a much lower percentage of snails carrying egg masses and a shorter period of reproduction (March through July only).

Abundance of snails smaller than $1 \mathrm{~mm}$ (Figure 4) showed that recruitment mainly occurred at Station 1 in the upper mudflat and to a lesser extent at Station 2. At Station 1, two maxima occurred: in August with $434 \pm 94$ ind $\mathrm{m}^{-2}$ and in December with $180 \pm 53$ ind $\mathrm{m}^{-2}$. At Station 2, the recruitment was characterized by a single peak in August with $219 \pm 71 \mathrm{ind}^{-2}$. At Station 3, a few recruits appeared in September $\left(47 \pm 28\right.$ ind $\left.\mathrm{m}^{-2}\right)$.

\section{Population structure}

Size-frequency analyses presented in Figure 5A,B and Table 1 (estimated parameters of cohorts) revealed that a maximum of five cohorts were identified, namely I, II, III, IV and V. According to the assumption of cohort analysis, the estimate of the standard deviation of each cohort (characterized by a gaussian distribution) did not change throughout the sampling year, except when densities were too low or when different cohorts merged in a single one.

In March 2000, cohorts I and II co-occurred at Stations 1 and 2 (with an estimated mean size of 4.3 and $1.9 \mathrm{~mm}$, respectively; Table 1). In May, cohorts I and II merged in a single one (estimated mean size of $4.3 \mathrm{~mm}$ ) and individuals were present at all three stations. Cohort III and cohort IV are recruited in July and August respectively, only at Stations 1 and 2. The last recruitment of the year (cohort $\mathrm{V}$, estimated mean size of $1.3 \mathrm{~mm}$ ) occurred in September at all three stations, but mainly at Stations 1 and 2. In October, cohorts I, II and III merged in a single one (estimated mean size of $4.6 \mathrm{~mm}$ ). Then, the major characteristics of the population structure were maintained until February 2001: three cohorts $(\mathrm{I}+\mathrm{II}+\mathrm{III}, \mathrm{IV}, \mathrm{V})$ co-occurred at Stations 1 and 2 with a predominance of juveniles at Station 1 and adults at Station 2; only the oldest cohort was recorded at Station 3. 


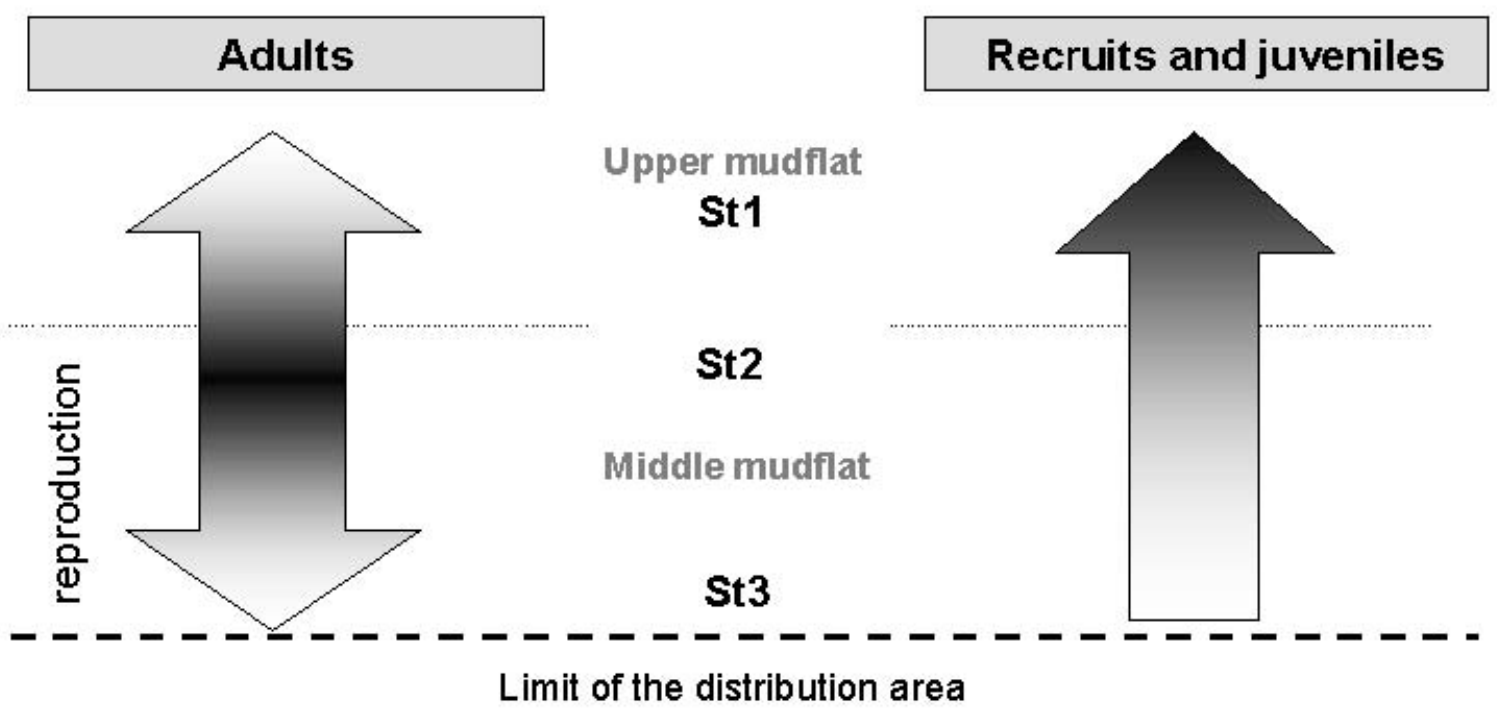

\section{Lower mudflat}

St4

Figure 9. Spatio-temporal differentiation in the population structure of Hydrobia ulvae on Brouage mudflat.

\section{Growth}

Growth curves of the different cohorts were built using the mean individual shell length at different dates (Figure 6), obtained from the results of the cohort analysis (Table 1). The maximum mean shell length of the population was $\sim 5 \mathrm{~mm}$. Only cohort III, which appeared in June, reached a size close to the maximum in October (4.7 $\mathrm{mm}$ at Station 1, $4.6 \mathrm{~mm}$ at Station 2); cohorts IV and $\mathrm{V}$, recruited later in the summer, stopped their growth in October at a shell length of $\sim 3.5$ and $2 \mathrm{~mm}$, respectively. There was no growth during the winter time from October 2000 until February 2001.

In order to model $H$. ulvae growth over a complete annual cycle, and assuming a steady state, growth curves were reconstructed by moving data of cohort II from March to September 2000 (see Figure 6), at the end of data from cohort V (Figure 7). This representation clearly shows the shape of the growth curve as a function of the time of recruitment; obviously, the growth rate changed as a function of seasons. A dynamic model, based on von Bertalanffy equation and including a variable growth parameter, was then fitted to the observed data to estimate the asymptotic maximum length $\left(\mathrm{L}_{\infty}\right)$ and the maximum growth rate $\left(k_{\max }\right)$ over the annual cycle. The estimated parameters of the von Bertalanffy growth function are not significantly different from Station 1 to Station 2 (statistical test proposed in Blanchard et al., 1997); $\mathrm{f}_{\mathrm{obs}}=0.92$ and $\left.P=0.65\right)$. Then, it turned out that $\mathrm{L}_{\infty}$ was $5.4 \pm 0.2 \mathrm{~mm}$ and $\mathrm{k}_{\max }$ was $0.47 \pm 0.5 \mathrm{~mm} \mathrm{month}^{-1}$.

\section{Cohort density fluctuations}

The abundance of each cohort showed large fluctuations during the sampling period (Figure 8), but the three stations were characterized by different patterns. At Station 1, all cohorts fluctuated, while at Station 2 cohorts with an average shell length larger than $3 \mathrm{~mm}$ showed larger fluctuations. Indeed, the largest cohorts $(\mathrm{I}+\mathrm{II}$ and $\mathrm{I}+\mathrm{II}+\mathrm{III})$, with an average shell length of $4.7 \pm 0.2 \mathrm{~mm}$, showed density fluctuations in the range 1500-6000 ind $\mathrm{m}^{-2}$ (the density significantly increased between May $(1830 \pm 218)$ and June (3490 \pm 325$)$, and between July $(2235 \pm 224)$ and August (5621 \pm 624$)$; Figure 8, Student $t$-test, $P<0.05)$ whereas densities of younger cohorts remained lower than 1500 ind $\mathrm{m}^{-2}$ until October. Similarly, cohort IV was subjected to large changes in abundance when its average shell length exceeded $3 \mathrm{~mm}$, while cohort $\mathrm{V}$ had a rather constant low density $\left(\sim 500\right.$ ind $\left.\mathrm{m}^{-2}\right)$, with an average shell length of about $2 \mathrm{~mm}$. At Station 3, only the largest cohort was present and showed occasional fluctuations in August (up

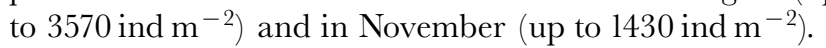

\section{DISGUSSION}

\section{Distribution, reproduction, recruitment and growth:} comparison with other areas

On Brouage mudflat, the population of Hydrobia ulvae was mainly distributed in the upper parts of the mudflat (Stations $1 \& 2$ of the present study; Figure 2), above the mean neap low-tide level. However, this distribution may differ between different areas: for instance, in the Gironde estuary, Bachelet (1987) recorded maximum densities at the mean tidal level during autumn, but in the lower part of the intertidal area during summer. On the other hand, Armonies \& Hartke (1995) also recorded maximum densities in the upper part of the mudflat, with a seaward extension during recruitment periods.

The Brouage population exhibited an extended spawning period since egg capsules were present most of the year with two peaks, in late spring and autumn 
(Figure 3). Such a pattern was also observed in several sites of southern Europe: the Gironde estuary in France (Bachelet \& Yassine-Kassab, 1987), the Bidasoa estuary in Spain (Sola, 1996) and the Mondego estuary in Portugal (Lillebo et al., 1999). Further north, populations from the Baltic Sea and the British Isles exhibit shorter spawning periods with a single peak in spring (Anderson, 1971; Lappalainen, 1979).

Despite the continuous flux of recruited juveniles from June to February (Figure 4) three cohorts between June and September were identified (Figures 5A,B \& 6); another recruitment occurred in December but densities were too low to separate this cohort from the others. After spawning, about a two-month time lag (corresponding to the embryonic development, the pelagic larval stage and the post-larval growth) is necessary to detect new recruits on a 500- $\mu \mathrm{m}$ mesh (Fish \& Fish, 1974; Bachelet \& Yacine-Kassab, 1987). Accordingly (Figures 4 \& 5), cohort III, recruited in July, may correspond to the increasing phase of spawning in May; cohort IV, recruited in August, may correspond to the spawning peak in June; cohort V, recruited in September, may correspond to the decreasing phase of spawning in July; individuals recruited in December may correspond to the slight renewal of spawn which occurred in September. Three annual cohorts were also recorded in the Gironde estuary (Bachelet \& Yassine-Kassab, 1987).

The present study is the first to provide a dynamic model based on von Bertalanffy equation which quantitatively estimates growth parameters of $H$. ulvae. The growth rate changed during the annual cycle as a function of the time of recruitment (Figure 7) and was maximum during summer at about $0.47 \mathrm{~mm}$ month ${ }^{-1}$. When cohorts were recruited in late summer or autumn, the growth curve was characterized by two phases because growth ceased during the winter (Figure 7). However, in every case, the maximum mean shell length was $\sim 5 \mathrm{~mm}$. These characteristics are similar to southern European sites: for instance, Bachelet \& Yassine-Kassab (1987) in the Gironde estuary and Sola (1996) in Spain have also recorded a two-phase growth for cohorts recruited in summer, with a similar average shell length. On the other hand, populations in northern Europe show lower growth rates. In the Anse Lostrouc'h (Finistère, France) Barnes (1996) have recorded similar maximum average shelllength (between 4 and $5 \mathrm{~mm}$ ) but the recruited cohort showed low and constant growth rates and reached the pool of larger individuals after about eight months. In the Dovey estuary (Anderson, 1971), the annual recruited cohort reached a shell length of $2 \mathrm{~mm}$ after one year.

\section{Differentiation in the population structure of Hydrobia ulvae}

The fact that the same growth rate was found at Stations 1 and 2 suggests that we observed the same population along the cross-shore transect during the whole sampling period. Thus, growth of $H$. ulvae can be estimated from any station on the mudflat. On the contrary, this population exhibited a strong spatio-temporal differentiation in its size-structure, which appears as a strong feature of $H$. ulvae populations on intertidal mudflats. Indeed, similar findings were also observed by Fish \& Fish in the Dovey estuary (1974) and by Armonies \&
Hartke (1995) in the Wadden Sea. In Brouage mudflat, recruitment events induced this differentiation in the population structure with a clear predominance of juveniles in the upper mudflat (Station 1 from June; Figure 5) and adults in the middle mudflat (at Station 2 and more particularly at Station 3). Taken together with the large fluctuations in the cohort densities observed at all stations, this feature emphasizes the fact that the local population structure (at any single site) is strongly influenced by large-scale movements, which make the interpretation of population dynamics particularly difficult and preclude the calculation of cohort mortality and population secondary production. As the spatial distribution of species involves both physical and biological processes (Newell, 1979), differential responses to these processes during the life cycle of $H$. ulvae must be taken into account to understand its population structure.

Recruitment pattern: we can hypothesize that the recruitment pattern along the transect mainly results from hydrodynamic processes. According to the density of mature individuals along the transect (Figure 3), the maximum density of recruits was expected to occur in the middle part of the mudflat (at Stations $2 \& 3$ ). As a result of larval dispersion, recruitment mainly occurred in the upper level (Station 1), to a lesser extent at Station 2, and almost no recruitment was observed at Station 3. Furthermore, the December recruitment was only detected at Station 1 (Figure 4) where reproduction stopped in August. Therefore, there seems to be a preferential settlement due to an importation of post-larvae at Station 1 from other sites (Stations $2 \& 3$ might be such sites, but it can be any sites even from outside the transect). This hypothesis is well supported by the fact that planktonic larvae are considered as passive particles (Hannan, 1984; Butman, 1989; Eckman, 1990), and as such the spatial pattern of recruitment is strongly influenced by physical factors (Eckman, 1983; Snelgrove, 1994; Emerson \& Grant, 1991). This is probably the case at Brouage mudflat where maximum flood velocities occur in the lower part of the mudflat and decrease towards the shore (Le Hir et al., 2000), thus producing an onshore residual flux of particles (Bassoulet et al., 2000) and very likely a preferential accumulation and settlement of post-larvae in the upper mudflat. Bouma et al. (2001) have reported similar explanations for the observed recruitment pattern of Cerastoderma edule and Macoma balthica.

However, compared to other European sites-e.g. the Gironde estuary in France (Bachelet \& Yassine-Kassab, 1987), and the Bidasoa estuary in Spain (Sola, 1996) with $\sim 10,000$ ind $\mathrm{m}^{-2}$ - the upper part of Brouage mudflat

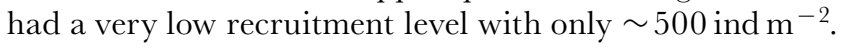
This 20-fold difference calls for two complementary explanations. The first one, based on Rhoads (1970) and Woodin (1976) studies, stipulates that new recruits of Hydrobia overcome a detrimental effect (through predation, interspecific competition) of the high densities of Scrobicularia plana, Macoma balthica and Abra tenuis populations characteristic of Station 1 (Sauriau et al., 1989). The second one suggests that the upper mudflat was not the main site for recruitment and that we only observed a residual recruitment, the main site not being covered by our transect. This hypothesis is supported by the fact that juveniles of a larger size appeared in the upper parts of the 
mudflat (Stations $1 \& 2$ ) during several months following the initial recruitment event (Figure 8). This sequential arrival of juveniles could be the result of a secondary dispersal by drifting behaviour (Armonies, 1992; Armonies \& Hartke, 1995) from a primary settlement site, as it was reported for several benthic invertebrates (Armonies, 1994; Olivier et al., 1996; Blackmon \& Eggleston, 2001) and particularly for H. ulvae in the Wadden Sea (Armonies \& Hartke, 1995). This behaviour responds to unfavourable biological and/or physical conditions (Olivier et al., 1996; Blackmon \& Eggleston, 2001) but the direction of transport is strongly influenced by hydrodynamics (Armonies \& Hartke, 1995).

Distribution pattern of adults: snail abundances were higher at Station 2 than at Station 1 (Figure 5) and individuals larger than $3 \mathrm{~mm}$ seemed to be imported from other parts of the mudflat (Figure 8). These snails were transported by currents but the determinism - resuspension induced by currents or active lifting into the water column-and the scale of their displacement cannot be determined in the present study. This also clearly demonstrates that the population structure cannot be understood from local information only. Moreover, within Station 2, the population was often rather contained in runnels (see Figure 2) which act as drainage structures during the ebb tide and also constrain the water flow during flood tide. Snails accumulated preferentially in these structures and were thus susceptible to move upwards and downwards around Station 2. The presence of runnels probably facilitates movements of Hydrobia in the middle part of the mudflat and might play an important role in the transport and exchange of individuals.

At Station 1, the lower abundance of adults may result from: (i) a differential mortality with higher loss rates at Station 1 (due to higher predation by birds or to higher parasitism than at Station 2); and (ii) active resuspension of adults to escape unfavourable conditions.

\section{CONCLUSION}

The population of Hydrobia ulvae on Brouage mudflat shows similar breeding and growth characteristics than that of other populations in southern Europe. Our study confirms the existence of large movements of $H$. ulvae, at the scale of the ecosystem, and shows a spatial differentiation in the population structure likely due to differential responses to physical and biological processes during the life cycle. Particularly, the spatial pattern of recruits and juveniles seems to be strongly influenced by hydrodynamics. These hypotheses, summarized in Figure 9, need to be tested by a modelling approach and an identification of the spatial structures of $H$. ulvae population at the end of the recruitment period. This should allow the larval dispersion pattern by hydrodynamical processes and mass transfers of individuals at the scale of the mudflat to be investigated.

This study forms part of the PhD thesis of A.G.H. This work was financially supported by the 'Conseil Général de CharenteMaritime' and the Poitou-Charentes Région. V. Huet, O. Herlory, G. Mairesse and X. de Montaudouin are gratefully acknowledged for their help.

\section{REFERENCES}

Aarnio, K. \& Mattila, J., 2000. Predation by juvenile Platichtys flesus (L.) on shelled prey species in a bare sand and a drift algae habitat. Hydrobiologia, 440, 347-355.

Admiraal, W., 1984. The ecology of estuarine sedimentinhabiting diatoms. In Progress in phycological research, vol. 3 (ed. F.E. Round and D.J. Chapman), pp. 269-322. Bristol: Biopress Ltd.

Anderson, A., 1971. Intertidal activity, breeding and the floating habit of Hydrobia ulvae in the Ythan estuary. Fournal of the Marine Biological Association of the United Kingdom, 51, 423-437.

Armonies, W., 1992. Migratory rhythms of drifting juvenile molluscs in tidal waters of the Wadden Sea. Marine Ecology Progress Series, 83, 197-206.

Armonies, W., 1994. Turnover of postlarval bivalves in sediments of tidal flats in Königshafen (German Wadden Sea). Helgoländer Meeresuntersushungen, 48, 291-297.

Armonies, W. \& Hartke, D., 1995. Floating of mud snails Hydrobia ulvae in tidal waters of the Wadden Sea, and its implications in distribution patterns. Helgoländer Meeresuntersushungen, 49, 529-538.

Bachelet, G., 1987. Processus de recrutement et rôle des stades juvéniles d'invertébrés dans le fonctionnement des systèmes benthiques de substrat meuble en milieu intertidal estuarien. Thèse $\mathrm{d}^{\prime} \mathrm{Etat}$, Bordeaux 1 , France.

Bachelet, G. \& Yacine-Kassab, M., 1987. Intégration de la phase post recrutée dans la dynamique des populations du gastéropode Hydrobia ulvae (Pennant). Fournal of Experimental Marine Biology and Ecology, 111, 37-60.

Barnes, R.S.K., 1990. Reproductive strategies in contrasting populations of the coastal gasteropod Hydrobia ulvae. II. Longevity and life-time egg production. Fournal of Experimental Marine Biology and Ecology, 138, 183-200.

Barnes, R.S.K., 1996. Breeding, recruitment and survival in a mixed intertidal population of the mudsnails Hydrobia ulvae and H. neglecta. Fournal of the Marine Biological Association of the United Kingdom, 76, 1003-1012.

Barnes, R.S.K., 1998. The effects of movement on population density estimates of mudflat epifauna. Fournal of the Marine Biological Association of the United Kingdom, 78, 377-385.

Barnes, R.S.K. \& Villiers, C.J. de, 2000. Animal abundance and food availability in coastal lagoons and intertidal marine sediments. Fournal of the Marine Biological Association of the United Kingdom, 80, 193-202.

Bassoullet, P., Le Hir, P., Gouleau, D. \& Robert, S., 2000. Sediment transport over an intertidal mudflat: field investigations and estimation of fluxes within the 'Baie de MarennesOléron' (France). Continental Shelf Research, 20, 1635-1653.

Blackmon, D.C. \& Eggleston, D.B., 2001. Factors influencing planktonic, post-settlement dispersal of early juvenile blue crabs (Callinectes sapidus Rathbun). Fournal of Experimental Marine Biology and Ecology, 257, 183-203.

Blanchard, G.F. \& Guarini, J.M., 1998. Temperature effects on microphytobenthic productivity in temperate intertidal mudflat. Vie et Milieu, 48, 271-284.

Blanchard, G.F., Guarini, J.M., Gros, P. \& Richard, P., 1997. Seasonal effect on the relationship between the photosynthetic capacity of intertidal microphytobenthos and temperature. Fournal of Phycology, 33, 723-728.

Bouma, H., Duiker, J.M.C., Vries, P.P. de, Herman, P.M.J. \& Wolff, W.J., 2001. Spatial pattern of early recruitment of Macoma balthica (L.) and Cerastoderma edule (L.) in relation to sediment dynamics on a highly dynamic intertidal sandflat. Journal of Sea Research, 45, 79-93.

Butman, C.A., 1989. Sediment-trap experiments on the importance of hydrodynamical processes in distributing settling invertebrate larvae in near-bottom waters. Fournal of Experimental Marine Biology and Ecology, 134, 37-88. 
Cariou-Le Gall, V. \& Blanchard, G.F., 1995. Monthly measurements of pigment concentration from an intertidal muddy sediment of Marennes-Oléron Bay, France. Marine Ecology Progress Series, 121, 171-179.

Cloern, J.E. \& Nichols, F.H., 1972. A von Bertalanffy growth model with a seasonally varying coefficient. Fournal of the Fisheries Board of Canada, 35, 1479-1482.

Colijn, F. \& Jonge, V.N. de, 1984. Primary production of microphytobenthos in the Ems-Dollard Estuary. Marine Ecology Progress Series, 14, 185-196.

Eckman, J.E., 1983. Hydrodynamic processes affecting benthic recruitment. Limnology and Oceanography, 28, 241-257.

Eckman, J.E., 1990. A model of passive settlement by planktonic larvae onto bottoms of differing roughness. Limnology and Oceanography, 35, 887-901.

Emerson, C.W. \& Grant, J., 1991. The control of soft-shell clam (Mya arenaria) recruitment on intertidal sandflats by bedload sediment transport. Limnology and Oceanography, 36, 1288-1300.

Evans, A., 1987. Relative availability of the prey of wading birds by day and by night. Marine Ecology Progress Series, 37, 103-107.

Fenchel, T., Kofoed, L.H. \& Lappalainen, A., 1975. Particle sizeselection of two deposit feeders: the amphipod Corophium volutator and the prosobranch Hydrobia ulvae. Marine Biology, 30, 119-128.

Fish, J.D. \& Fish, S., 1974. The breeding cycle and growth of Hydrobia ulvae in the Dovey estuary. Fournal of the Marine Biological Association of the United Kingdom, 54, 685-697.

Gouleau, D., Jouanneau, J.M., Weber, O. \& Sauriau, P.G., 2000. Short- and long-term sedimentation on Montportail-Brouage intertidal mudflat, Marennes-Oléron Bay (France). Continental Shelf Research, 20, 1513-1530.

Hannan, G.A., 1984. Planktonic larvae may act like passive particles in turbulent near-bottom flows. Limnology and Oceanography, 29, 1108-1116.

Hasselblad, V., 1966. Estimation of parameters for a mixture of Normal Distributions. Technometrics, 3, 431-446.

Jensen, K.T. \& Siegismund, H.R., 1980. The importance of diatoms and bacteria in the diet of Hydrobia-species. Ophelia, $\mathbf{1}$, 193-199.

Lappaleinen, A., 1979. Seasonal recruitment and population structure of coexisting mudsnails (Hydrobiidae). Ophelia, 18, 171-178.

Le Hir, P., Roberts, W., Cazaillet, O., Christie, M., Bassoulet, P.H. \& Bacher, C., 2000. Characterisation of intertidal flat hydrodynamics. Continental Shelf Research, 20, 1433-1459.

Lillebo, A.I., Pardal, M.A. \& Marques, J.C., 1999. Population structure, dynamics and production of Hydrobia ulvae (Pennant) (Mollusca: Prosobranchia) along an eutrophication gradient in the Mondego estuary (Portugal). Acta Oecologica, 20, 289-304.
Little, C. \& Nix, W., 1976. The burrowing and floating behaviour of the gastropod Hydrobia ulvae. Estuarine and Coastal Marine Science, 4, 537-544.

Lopez, G.R. \& Kofoed, L.H., 1980. Epipsammic browsing and deposit-feeding in mud snails (Hydrobiidae). Fournal of Marine Research, 38, 585-599.

Morrisey, D.J., 1988. Differences in effects of grazing by depositfeeders Hydrobia ulvae (Pennant) (Gasteropoda: Prosobranchia) and Corophium arenarium Crawford (Amphipoda) on sediment microalgal populations. I. Qualitative differences. Fournal of Experimental Marine Biology and Ecology, 118, 33-42.

Nelder, V.A. \& Mead, R., 1965. A simplex method for function minimization. The Computer Fournal, 7, 308-313.

Newell, R., 1965. The role of detritus in the nutrition of two marine deposit-feeders, the prosobranch Hydrobia ulvae and the bivalve Macoma balthica. Proceedings of the Zoological Society of London, 144, 25-45.

Newell, R., 1979. Biology of intertidal animals. Faversham, Kent: Marine Ecological Survey Ltd.

Olivier, F., Vallet, C., Dauvin, J.-C. \& Retière, C., 1996. Drifting in post-larvae and juveniles in an Abra alba (Wood) community of the eastern part of the Bay of Seine (English Channel). Journal of Experimental Marine Biology and Ecology, 199, 89-109.

Rhoads, D.C., 1970. The influence of deposit-feeding organisms on sediment stability and community trophic structure. Fournal of Marine Research, 28, 150-178.

Sauriau, P.-G., Mouret, V. \& Rincé, J.-P., 1989. Organisation trophique de la malacofaune benthique non cultivée du bassin ostréicole de Marennes-Oléron. Oceanologica Acta, 12, 193-204.

Snelgrove, P.V.R., 1994. Hydrodynamics enhancement of invertebrate larval settlement in microdepositionnal environments: colonization tray experiments in a muddy habitat. Fournal of Experimental Marine Biology and Ecology, 176, 149-166.

Sola, J.C., 1996. Population dynamics, reproduction, growth, and secondary production of the mud-snails Hydrobia ulvae (Pennant). Fournal of Experimental Marine Biology and Ecology, 205, 49-62.

Tomlinson, P.K., 1970. The resources agency of California, Department of Fish and Game. Program NORMSEP (Fortran IV).

Woodin, S.A., 1976. Adult-larval interactions in dense infaunal assemblages: patterns of abundance. Fournal of Marine Research, 34, 25-41.

Submitted 25 October 2001. Accepted 22 April 2002. 